\title{
ANALISIS KESALAHAN PENULISAN KATA PADA KARANGAN DESKRIPSI SISWA KELAS VIII SMP NEGERI 2 SEKAYU
}

\author{
FITRIANI \\ Email: fitrianipratama603@gmail.com \\ Guru SMP Negeri 2 Sekayu
}

\begin{abstract}
Abstrak - Masalah dalam penelitian ini adalah "Bagaimanakah kesalahan penulisan kata dalam karangan deskripsi siswa kelas VIII SMP Negeri 2 Sekayu?". Penelitian ini bertujuan mendeskripsikan kesalahan penulisan kata pada karangan deskripsi siswa kelas VIII SMP Negeri 2 Sekayu. Penelitian ini merupakan penelitian kualitatif deskriptif. Jenis data yang diperoleh dalam penelitian ini adalah data tertulis yang bersumber dari karangan deskripsi siswa SMP Negeri 2 Sekayu. Pengumpulan data dilakukan dengan menggunakan teknik tes, dokumentasi, pengamatan, dan pencatatan. Berdasarkan hasil penelitian, diperoleh kesalahan-kesalahan penulisan karangan deskripsi siswa SMP Negeri 2 Sekayu, yang meliputi kesalahan penulisan kata, penggunaan kata depan, penggunaan singkatan, penggunaan kata ulang, penggunaan tanda hubung dan kesalahan penggunaan penggunaan imbuhan. Kesalahan ini disebabkan karena faktor kurangnya pemahaman siswa tentang penulisan kata-kata yang baik dan benar yang mendasari pokok permasalahan dalam penelitian ini. Dalam hal ini, siswa harus dibekali tatacara menulis karangan menurut kaidah-kaidah dalam ejaan yang disempurnakan.
\end{abstract}

Kata Kunci : Kesalahan penulisan kata, Karangan deskripsi

\begin{abstract}
The problem in this study is "What is the writing error of the word in the description of class VIII students of SMP 2 Sekayu?". This study aims to describe the writing errors in the description essays of class VIII students of SMP Negeri 2 Sekayu. This research is a descriptive qualitative study. The type of data obtained in this study is written data sourced from the description of students of Sekayu 2 Public Middle School. Data collection is done using test techniques, documentation, observation, and recording. Based on the results of the study, it was obtained the writing errors of the description of Sekayu 2 Public Middle School students, which included word writing errors, the use of prepositions, the use of abbreviations, the use of repeated words, the use of hyphens and the use of additive errors. This error is caused by a lack of understanding of students about writing good and true words that underlie the main problems in this study. In this case, students must be provided with writing procedures according to the rules in an enhanced spelling.
\end{abstract}

\section{Keywords: Word writing errors, Description essays}

PENDAHULUAN

Menulis merupakan salah-satu

keterampilan berbahasa yang digunakan untuk mengungkapkan pikiran, gagasan dan untuk menyampaikan pesan melalui bahasa tulis sebagai alat atau medianya, agar mudah untuk dipahami oleh pembaca. Pemilihan kata dan tata tulis menjadi salah satu persyaratan yang harus dipenuhi oleh seorang penulis. Sebagai suatu keterampilan berbahasa, menulis merupakan kegiatan yang kompleks karena penulis dituntut untuk dapat menyusun dan mengorganisasikan isi tulisannya serta menuangkannya dalam formulasi ragam bahasa tulis dan konvensi penulisan lainnya.

$$
\text { Begitu pentingnya keterampilan }
$$

menulis sehingga setiap penulis harus memiliki wawasan yang luas tentang tata tulis. 
Pentingnya tata tulis dalam rangka memenuhi aspek keterampilan ide dan kesatuan konvensi tata tulis berdasarkan ejaan bahasa Indonesia yang baik dan benar. Dalam pembelajaran siswa dituntut untuk menulis, karena menulis merupakan kewajiban bagi siswa dan tidak dapat dipisahkan dalam proses pembelajaran. Dari keterampilan berbahasa termasuk di dalamnya adalah keterampilan menulis. Keterampilan menulis adalah keterampilan yang dapat menghasilkan kata dan kalimat. Keterampilan tersebut disebut juga sebagai keterampilan produktif. Menulis juga dapat menghasilkan karya-karya tulis yang dapat dibaca oleh banyak orang. Karena itu menulis sangat penting bagi seorang pelajar khususnya di SMP Negeri 2 Sekayu. Pentingnya siswa mempelajari keterampilan menulis, siswa harus diperkenalkan cara-cara penulisan kata yang baik dan benar.

Harimurti Kridalaksana, (2001:12) menyatakan bahwa analisis bahasa adalah isitilah umum untuk berbagai kegiatan yang dilakukan oleh penyelidik bahasa dalam menggarap data yang diperoleh dari penelitian lapangan atau dari pengumpulan teks. Analisis ini disebut juga sebagai analisis kesilapan.

\section{Menurut Crystal, (Gantamitreka,} 2016:201), analisis kesalahan berbahasa adalah salah satu teknik untuk mengidentifikasi, mengiterpretasi secara sistematis kesalahankesalahan yang dilakukan siswa dalam pembelajaran B2 (bahasa asing). Dengan menggunakan teori-teori dan prosedur-prosedur yang mempunyai hubungan dengan pembahasan. Sedangakan Corder (Gantamitreka, 2016:201), mengemukakan bahwa analisis kesalahan berbahasa merupakan suatu proses atau prosedur yang harus dituruti selaku pedoman kerja. Prosedur tersebut terbagi lima yaitu : (1) memilih korpus bahasa, (2) mengenali kesalahan dalam korpus, (3) mengklasifikasikan kesalahan, menjelaskan kesalahan, (5) mengevaluasi kesalahan.

Dapat disimpulkan bahwa kesalahan berbahasa adalah suatu proses kerja yang digunakan oleh guru dan peneliti bahasa dengan langkah-langkah pengumpulan data, pengidentifikasian data, penjelasan kesalahan tersebut, pengklasifikasian kesalahan itu berdasarkan penyebabnya, serta mengevaluasi taraf keseriusan kesalahan itu.

Berdasarkan paparan di atas, peneliti tertarik untuk melakukan penelitian di SMP Negeri 2 Sekayu. Alasan peneliti mengambil judul tersebut karena belum pernah dilakukan penelitian ini di SMP Negeri 2 Sekayu mengenai analisis penulisan kata pada karangan deskripsi. Berdasarkan beberapa pendapat mengenai kesalahan berbahasa yang dikemukakan di atas, dapat disimpulkan bahwa kesalahan berbahasa Indonesia adalah pemakaian unit kebahasaan tertentu seperti pemakaian fonem, bentuk kata, kalimat, paragraf, serta pemakaian ejaan yang melanggar aturan atau kaidah bahasa Indonesia baku. Kriteria yang menjadi acuan kesalahan berbahasa Indonesia kaidah berbahasa Indonesia baku dan pedoman umum ejaan bahasa Indonesia yang disempurnakan. 
Berdasarkan latar belakang di atas rumusan masalah peneliti ini yaitu, Bagaimanakah kesalahan penulisan kata dalam karangan deskripsi siswa kelas VIII SMP Negeri 2 Sekayu? Tujuan dilakukan penelitian ini untuk mendeskripsikan kesalahan penulisan kata pada karangan deskripsi siswa kelas VIII SMP Negeri 2 Sekayu. Penelitian ini dilakukan untuk memperoleh manfaat baik secara teoritis maupun secara praktis. Secara teoritis ini memberi manfaat untuk memperdalam pemahaman tentang penulisan kata pada keterampilan menulis secara umum dan secara khusus dalam menulis karangan deskripsi. Namun secara praktis penelitian ini dapat memberi manfaat sebagai berikut:

1 Bagi siswa yaitu sebagai motivasi bagi siswa agar dapat mengembangkan keterampilan menulis sehingga tidak lagi memiliki kesalahan dalam penulisan karangan.

2 Bagi guru untuk memberi masukan untuk guru, khususnya pada pelajaran bahasa Indonesia dalam keterampilan menulis kesalahan pada tulisan dapat diminimalkan agar tidak mengalami kesalahan

3. Bagi sekolah yaitu sebagai bahan acuan siswa dan guru di dalam sebuah pembelajaran dan sebagai referensi sehingga dapat memperoleh wawasan khusunya dalam kesalahan penulisan kata..

4. Bagi peneliti yaitu dapat memperdalam pengetahuan penelitian mengenai analisis kesalahan penulisan dan dapat dijadikan rujukan bagi penelitian selanjutnya.

\section{LANDASAN TEORI}

\section{Analisis Kesalahan Berbahasa}

Harimurti, (2001:12) analisis bahasa yaitu istilah umum untuk berbagai kegiatan yang dilakukan oleh penyelidik bahasa dalam menggarap data yang diperoleh dari penelitian lapangan atau dari pengumpulan teks. Analisis kesilapan yaitu teknik untuk mengukur kemajuan belajar bahasa dengan mencatat dan mengklasifikasikan kesalahan-kesalahan yang dibuat oleh seseorang atau sekelompok. Harimurti (2001:13). Menurut Crystal, (dalam Gantamitreka, 2016:201), analisis kesalahan berbahasa adalah salah satu teknik untuk mengidentifikasi, menginterpretasi secara sistematis kesalahan-kesalahan yang dilakukan siswa dalam pembelajaran B2 (bahasa asing) dengan menggunakan teori-teori dan prosedurprosedur yang ada hubungannya dengan pembahasaan.

Dengan demikian, dapat disimpukan bahwa kesalahan berbahasa adalah suatu proses kereja yang digunakan oleh guru dan peneliti bahasa dengan langkah- langkah pengumpulan data, pengidentifikasian kesalahan terdapat dalam data, penjelasan kesalahan tersebut, pengklasifikasian kesalahan itu berdasarkan penyebabnya, serta pengevaluasian taraf keseriusan kesalahan itu. Dengan demikian, dapat disimpukan bahwa kesalahan berbahasa adalah suatu proses kerja yang digunakan oleh guru dan peneliti bahasa dengan langkah-langkah pengumpulan data, pengidentifikasian kesalahan terdapat dalam data, penjelasan kesalahan tersebut, pengklasifikasian kesalahan itu berdasarkan 
penyebabnya, serta pengevaluasian taraf keseriusan kesalahan itu.

Tarigan, (Gantamitreka 2016:202), mengajukan langkah menganalisis kesalahan berbahasa yang merupakan modifikasi langkahlangkah analisis kesalahan berbahasa yang diajukan Ellis dan Sidhar. Langkah-langkah menganalisis kesalahan berbahasa dijelaskan sebagai berikut.

1. Mengumpulkan data yang berupa kesalahan-kesalahan berbahasa yang dibuat pelajar.

2. Mengidentifikasi dan mengklasifikasi kesalahan; terhadap pengenalan pemilahmilahan kesalahan berdasarkan kategori kebahasaan.

3. Membuat peringkat kesalahan yang berarti membuat urutan kesalahan berdasarkan kesalahan-kesalahan itu muncul.

4. Menjelaskan kesalahan dengan mendeskripsikan letak kesalahan, sebabsebabnya dan pemberian contoh yang benar.

5. Membuat perkiraan daerah atau butir kebahasaan yang rawan menyebabkan kesalahan.

6. Mengkoreksi kesalahan yang berupa pembetulan dan penghilangan kesalahan berupa penyusunan bahan yang tepat dan penentuan strategi pembelajaran yang serasi.

\section{Kesalahan Berbahasa dalam Penerapan Kaidah Ejaan yang Disempurnakan}

Kaidah ejaan dalam tata tulis sangat penting. Kesalahan ejaan dapat menimbulkan kesalahan tanggapan pembaca terhadap gagasan yang dikemukakan oleh penulis. Gantamitreka, (2016:179). Pendapat lain Gantamitreka, (2016:9), ejaan adalah kaidahkaidah cara penggambaran bunyi-bunyi (kata, kalimat, dan sebagainya) dalam bentuk tulisan (huruf-huruf) serta penggunaan tanda baca. Menurut Setyawati, (2010:156), secara teknis ejaan adalah aturan tulis- menulis dalam suatu bahasa yang berhubungan dengan penulisan huruf, penulisan kata, penulisan unsur serapan, dan penggunaan tanda baca.

Berdasarkan pendapat di atas, dapat disimpulkan bahwa ejaan adalah aturan tulismenulis dalam menggambarkan suatu bahasa yang berhubungan dengan penulisan huruf, penulisan kata, penulisan unsur serapan, dan penggunaan tanda baca.

\section{Penulisan Kata}

Penulisan kata merupakan proses atau cara menulis sebuah karya yang mempertimbangkan unsur-unsur bahasa yang dituliskan sebagai wujud kesatuan, perasaan dan pikiran yang dapat digunakan dalam berbahasa sesuai dengan ejaan yang disempurnakan (EYD).

\section{Penulisan Kata}

\section{Kata Dasar}

Kata dasar ditulis sebagai satu kesatuan.

Misalnya:

Kantor pajak penuh sesak Saya pergi ke sekolah Buku itu sangat tebal 


\section{Kata Berimbuhan}

Imbuhan (awalan, sisipan, akhiran serta gabungan awalan dan akhiran) ditulis serangkai dengan bentuk dasarnya.

Misalnya: Berjalan berkelanjutan mempermudah gemetar lukisan kemauan

\section{Kata Ulang}

Bentuk ulang ditulis dengan menggunakan dengan tanda hubung (-) di antara unsurunsurnya

Misalnya:

Anak-anak, hati-hati, Buku-buku, kura-kura, Ramah-tamah, terus-menerus,

Mencari-cari, porak-poranda, Mata-mata, mondar-mandir

\section{Gabungan Kata}

Unsur gabungan kata yang lazim disebut kata majemuk, termasuk istilah khusus, ditulis terpisah Misalnya:

duta besar, model linear, kambing, hitam, persegi panjang, orang tua, rumah sakit jiwa, simpang empat, meja tulis

\section{Pemenggalan kata}

Pemenggalan kata pada kata dasar dilakukan sebagai berikut.

a. Jika di tengah ada huruf vokal yang berurutan, pemenggalannya dilakukan di antara huruf vokal itu.

Misalnya:

bu-ah ma-in

ni-at sa-at

\section{Kata Depan}

kata depan, seperti di, ke, dan dari, ditulis terpisah dari kata yang mengikutinya.

Misalnya:
Di mana dia sekarang?

Kain itu disimpan di dalam lemari. Mari kita berangkat ke kantor.

Saya pergi ke sana kemari mencarinya. la berasal dari pulau penyengat. Cincin itu terbuat dari emas

\section{Partikel}

Partikel -lah -kah, dan -tah ditulis serangkai denagan kata yang mendahuluinya.

\section{Singkatan}

Singkatan nama orang, gelar, sapaan, jabatan, atau pengkat, diikuti dengan tanda titik pada sitiap unsur singkatan itu. Misalnya:

A.H. Nasution Abdul Haris Nasution

H. Hamid Haji Hamid Suman Hs. SumanHasibuan M.SI Master Sains S.Kom Sarjana Komunikasi

\section{Akronim}

Akronim nama diri yang terdiri atas huruf awal setiap kata ditulis dengan huruf kapital tanpa tanda titik.

Misalnya:

BIG Badan Informasi Geospasial BIN Badan Intelejen Negara

LAN Lembaga Administrasi Negara.

\section{Pengertian Karangan}

Menurut Poerwodarminta (1984:445), "Karangan merupakan uraian tentang sesuatu hasil". Dengan demikian, pengertian karangan atau tulisan dapat kita batasi sebagai rangkaian kalimat yang logis, padu, sistematis, yang berisi pengalaman, pikiran atau pelukisan tentang 
objek suatu peristiwa atau suatu masalah. Kemampuan mengarang adalah kemampuan untuk menuangkan gagasan dalam sebuah karangan. Dalam kaitan itu, seorang penulis dituntut memiliki kemampuan untuk menuangkan gagasannya secara berjenjang.

\section{Penyusunan Rancangan Karangan}

Menurut Suparno dkk, (2007:3.8) Penyusunan kerangka karangan adalah langkah kegiatan penulisan setelah penentuan topik. Kerangka karangan adalah kerangka tulis yang menggambarkan bagian-bagian atau butir-butir isi karangan dalam tatanan yang sistematis. Karena tatanan yang sistematis itu, kerangka karangan sudah menunjukan organisasi isi karangan. Gambaran isi yang demikian itu menempatkan butir-butir isi karangan dalam hubungannya dengan butir-butir yang lain. Dalam kerangka karangan itu akan tampak butir-butir isi karangan yang menggambarkan (1) sub-subtopik, karangan baik dari segijumlah dan jenisnya, (2) urutan sub-subtopik isi karangan dan (3) hubungan antar subtopik dalam karangan hubungan logis dan kronologis dan hubungan setara atau hubungan bertingkat.

\section{Pengertian Karangan Deskripsi}

Suparno dkk, (2007:4.7) kata deskripsi berasal dari kata bahasa Latin describere yang berarti menggambarkan atau memeriahkan suatu hal. Dari segi istilah, deskripsi adalah suatu bentuk karangan yang melukiskan sesuai dengan keadaan sebenarnya, sehingga pembaca dapat mencitrai (melihat, mendengar, mencium dan merasakan) apa yang dilukiskan itu sesuai dengan citra penulisnya. Karangan jenis ini bermaksud menyampaikan kesan-kesan tentang sesuatu, dengan sifat dan gerakgeriknya, atau sesuatu yang lain kepada pembaca.

Karangan deskripsi adalah karangan yang melukiskan suatu keadaan, mengemukakan sifat, tingkah-laku seseorang, suasana dan keadaan sesuatu tempat atau sesuatu yang lain. Selanjutnya Suparno dkk, (2007:1.11) mengemukakan bahwa deskripsi adalah ragam wacana yang melukiskan sesuatu berdasarkan kesan- kesan dari pengamatan, dan perasaan penulisnya. Sasarannya adalah menciptakan atau memungkinkan terciptanya imajinasi (daya khayal) pembaca sehingga seolah-olah melihat, mengalami, dan merasakan sendiri apa yang dialami penulisnya.

Keraf, (1995: 26), menyatakan bahwa; deskripsi adalah semacam bentuk wacana yang berusaha menyajikan suatu objek atau suatu hal sedemikian rupa sehingga objek itu seolah-olah berada di depan pembaca, seolah-olah pembaca melihat sendiri objek itu. Sedangkan Tarigan, (1996:52), "Karangan deskripsi ialah tulisan yang berusaha memberikan perincian atau melukiskan dan mengemukakan objek yang sedang dibicarakan (seperti orang, tempat, suasana atau hal lain)". Dapat disimpulkan bahwa karangan deskripsi adalah ragam wacana yang melukiskan suatu objek berdasarkan kesan-kesan dari pengamatan seorang penulis sehingga pembaca seolah-olah melihat, mendengar, mencium, dan merasakan 
apa yang dilukiskan sesuai dengan penghayatan atau citraan penulisnya. Dengan demikian, karangan ini bertujuan menyampaikan kesan-kesan kepada pembaca karangan dengan melukiskan suatu keadaan tingkah laku seseorang dan keadaan suatu tempat.

\section{Macam-Macam Karangan Deskripsi}

\section{a. Deskripsi Sugestif}

Deskripsi sugestif ialah deskripsi yang bertujuan membangkitkan daya khayal, kesan atau sugesti tertentu, seolah-olah pembaca melihat sendiri objek (yang dideskripsikan) secara keseluruhan seperti yang dialami secara fisik oleh penulisnya.

\section{b. Deskripsi Teknis}

Deskripsi teknis ialah deskripsi yang bertujuan memberikan identifikasi atau informasi objek, sehingga pembaca dapat mengenal bila bertemu atau berhadapan dengan objek itu.

\section{Macam-Macam Karangan Deskripsi}

Menurut Suparno dkk, (2007:4.14), macam-macam karangan deskripsi dibedakan menjadi empat bagian yaitu deskripsi keadaan fisik, deskripsi alam sekitar, deskripsi watak atau tingkat perbuatan, dan deskripsi gagasangagasan tokoh, dipaparkan sebagai berikut.

1. Deskripsi keadaan fisik

Deskripsi fisik bertujuan memberi gambaran yang sejelas-jelasnya tentang keadaan tubuh seseorang tokoh.Deskripsi ini bersifat objektif.
2. Deskripsi alam sekitar

Deskripsi keadaan sekitar, yaitu penggambaran keadaan yang mengelilingi sang tokoh, misalnya penggambaran tentang aktivitas- aktivitas yang dilakukan, pekerjaan atau jabatan, pakaian, tempat kediaman, dan kendaraanyang ikut menggambarkan watak seseorang.

3. Deskripsi watak atau tingkat perbuatan

Mendeskripsikan watak seseorang memang paling sulit dilakukan kita harus mampu menafsirkan tabir yang terkandung dalam balik fisik manusia.Dengan kecermatan dan keahlian seseorang, seseorang harus mampu mengidentifikasikan unsur- unsur dan kepribadian seorang tokoh.Kemudian, menampilakan dengan jelas unsur-unsur yang dapat memperhatikan karakter yang digambarkan.

4. Deskripsi gagasan-gagasan tokoh Hal ini memang tidak dapat diserap oleh panca indra manusia. Namun, antara perasaan dan unsur fisik mempunyai hubungan yang erat.Pancaran wajah, pandangan mata, gerak bibir, dan gerak tubuh merupakan petunjuk tentang keadaan perasaan seseorang pada waktu itu.

\section{Ciri-ciri karangan deskripsi}

Dalman, (2015: 94) membedakan ciriciri khas pada karangan deskripsi yang dipaparkan sebagai berikut.

1 Deskripsi lebih memperlihatkan setai atau 
perincian tentang objek;

2 Deskripsi bersifat memberikan sensitivitas dan membentuk imajinasi pembaca;

3 Deskripsi disampaikan dengan gaya yang memikat;

4 Deskripsi dituliskan dengan pilihan kata yang menggugah;

5 Deskripsi memaparkan tentang sesuatu yang dapat dirasakan oleh pancaindera

\section{Langkah-Langkah Menulis Karangan Deskripsi}

1. Menulis karangan deskripsi perlu dilakukan langkah-langkah untuk membantu mempermudah pendeskripsian, berikut ini disajikan rambu-rambu yang dapat anda ikuti. Suparno dkk, (2007:4.22). Menentukan apa yang akan dideskripsikan: apakah akan mendeskripsikan orang atau tempat.

2. Merumuskan tujuan pendeskripsian: apakah deskripsi dilakukan sebagai alat bantu karangan narasi, eksposisi, argumentasi atau persuasi.

3. Menetapkan bagian yang akan dideskripsikan: kalau yang dideskripsikan orang, apakah yang akan dideskripsikan itu ciri fisik, watak, gagasannya, atau benda- benda disekitar tokoh. Kalau yang dideskripsikan tempat, apakah yang akan dideskripsikan keseluruhan tempat atau bagian-bagian tertentu saja yang menarik.

4. Merinci dan menyistematiskan hal-hal yang menunjang kekuatan bagian yang akan dideskripsikan: hal-hal apa saja yang akan ditampilkan untuk membantu munculnya kesan dan gambaran kuat mengenai sesuatu yang dideskripsikan? Pendekatan apa yang digunakan penulisan.

\section{METODELOGI PENELITIAN}

\section{Metode Penelitian}

Metode yang digunakan dalam penelitian ini adalah metode deskriptif. Menurut Semi (1993:24), "Penelitian deskriptif adalah data yang terurai dalam bentuk kata-kata atau gambar-gambar, bukan dalam bentuk angkaangka." Penelitian ini tidak menguji hipotesis atau tidak menggunakan hipotesis melainkan hanya mendeskripsikan informasi baik berupa pencatatan, dokumen, memoranda dan lainnya yang sesuai dengan variabel yang akan diteliti. Penelitian ini berusaha memaparkan dan memberikan data yang akurat tentang kesalahan penulisan kata pada karangan deskripsi siswa KELAS VIII SMP Negeri 2 Sekayu.

\section{Data dan Sumber Data}

Data yang digunakan dalam penelitian ini berbentuk data tulisan dan sumber data diperoleh dari hasil pekerjaan atau tes menulis karangan deskripsi pada siswa KELAS VIII SMP Negeri 2 Sekayu.

\section{Tempat dan Waktu Penelitian}

Tempat dilakukanya penelitian ini, yaitu di SMP Negeri 2 Sekayu yang terletak di Kota Sekayu. Alasan penulis memilih sekolah tersebut karena belum ada yang melakukan 
penelitian tentang analisis kesalahan penulisan kata pada karangan deskripsi di kelas VIII.1. Waktu penelitian ini dilaksanakan selama satu bulan.

\section{Teknik Pengumpulan Data}

Data dalam penelitian ini diperoleh melalui beberapa teknik, yaitu 1) teknik tes, 2) teknik dokumentasi, 3) teknik pengamatann dan 4) teknik catat. Keempat teknik tersebut diuraikan sebagai berikut:

\section{Teknik Analisis Data}

Data dalam penelitian ini dianalisis dengan menggunakan tiga cara, yakni 1) mereduksi data. 2) penyajian data, 3) penarikan kesimpulan.

\section{HASIL PENELITIAN DAN PEMBAHASAN}

\section{Hasil Penelitian}

Berdasarkan hasil penelitian diperoleh kesalahan ejaan dalam karangan deskripsi pada siswa kelas VIII SMP Negeri 2 Sekayu, meliputi kesalahan penulisan kata ulang, penulisan kata depan, penulisan singkatan,penulisan imbuhan. Keempat kesalahan pada penulisan kata dalam karangan deskripsi siswa diuraikan sebagai berikut.

\section{Kesalahan Penulisan Kata}

Kesalahan penulisan kata yang diperoleh dalam penelitian ini meliputi; kesalahan penulisan kata ulang, kesalahan penulisan kata depan dan kesalahan penulisan singkatan. Ketiga bentuk kesalahan pada penulisan kata dalam karangan deskripsi siswa diuraikan berikut ini:

\section{Kesalahan Penulisan Kata Ulang Data 1}

"habis makan kami duduk² sebentar habis duduk kami pulang"

Penulisan kata ulang tersebut, secara EYD menyalahi kaidah, seharusnya kata tersebut ditulis secara lengkap atau utuh dengan memberi garis penghubung atau mengulang kata dasar dengan memberi tanda hubung di antara kata dasar tersebut. Oleh karena itu, agar penulisan kata di atas, sesuai dengan EYD, penulisannya yang tepat dapat diperbaiki menjadi: "habis makan kami duduk- duduk sebentar habis duduk kami pulang"

\section{Data 2}

"karena kami laju laju sampai ditilang polisi"

Paparan data (2) di atas, tampak kesalahan penulisan kata ulang. Kesalahan itu dapat dilihat pada kata yang dicetak miring laju laju. Penulisan kata ulang tersebut, secara EYD menyalahi kaidah, seharusnya kata ulang tersebut ditulis secara lengkap atau utuh dengan memberi garis penghubung atau mengulang kata dasar dengan memberi tanda hubung di antara kedua kata dasar tersebut. Oleh karena itu, agar penulisan kata ulang di atas, sesuai dengan EYD, penulisannya dapat diperbaiki menjadi: "karena kami laju-laju sampai ditilang polisi".

Data 3

"saya menfoto foto dengan turis dan akhirnya saya pulang"

Paparan data (3) di atas, tampak kesalahan penulisan kata ulang. Kesalahan itu dapat dilihat pada kata yang dicetak miring menfoto foto. Penulisan kata ulang tersebut, 
secara EYD menyalahi kaidah, seharusnya kata tersebut ditulis secara lengkap atau utuh dengan memberi garis penghubung atau mengulang kata dasar dengan memberi tanda hubung diantara kata dasar tersebut. Oleh karena itu, agar penulisan kata di atas, sesuai dengan EYD, penulisannya dapat diperbaiki menjadi "saya menfoto- foto dengan turis dan akhirnya saya pulang"

\section{Data 4}

"pas pas saya pulang saya naik bus sekolah bersama kawan ${ }^{21}$

Paparan data (4) di atas, tampak kesalahan penulisan kata ulang. Kesalahan itu dapat dilihat pada kata yang dicetak miring pas pas, kawan². Penulisan kata ulang tersebut, secara EYD menyalahi kaidah, seharusnya kata tersebut ditulis secara lengkap atau utuh dengan memberi garis penghubung atau mengulang kata dasar dengan memberi tanda hubung diantara kata dasar tersebut. Oleh karena itu, agar penulisan kata di atas, sesuai dengan EYD, penulisannya dapat diperbaiki menjadi "pas-pas saya pulang saya naik bus sekolah bersama kawan-kawan"

\section{Data 5}

"saya pergi dengan kawan kawan saya melihat ramainya orang yang berlibur"

$$
\text { Paparan data (5) di atas, tampak }
$$
kesalahan penulisan kata ulang. Kesalahan itu dapat dilihat pada kata yang dicetak miring kawan-kawan. Penulisan kata ulang tersebut, secara EYD menyalahi kaidah, seharusnya kata ulang tersebut ditulis secara lengkap atau utuh dengan memberi garis penghubung atau mengulang kata dasar dengan memberi tanda hubung diantara kedua kata dasar tersebut. Oleh karena itu, agar penulisan kata ulang di atas, sesuai dengan EYD, penulisannya dapat dilihat menjadi"saya pergi dengan kawan-kawan saya melihat ramainya orang yang berlibur".

\section{Kesalahan Kata Depan}

Kata depan dapat ditandai dengan penggunaan kata seperti di, ke, dan dari, yang harus ditulis terpisah dengan kata yang mengikutinya. Tetapi dalam penelitian karangan deskripsi siswa di SMP Negeri 2 Sekayu masih banyak yang memiliki kesalahan dalam penulisan kata depan.

\section{Data 6}

"saya sesampai disana saya melihat orang yang sangat ramai mandi-mandi disana"

Kesalahan pada kata depan pada data (6) terdapat kata disana pada kata tersebut harusnya di pisah karena menunjukan keterangan tempat jadi, penulisan tersebut harus dipisah di sana berikut penulisan kata depan yang tepat "saya sesampai di sana saya melihat orang yang sangat ramai mandi-mandi di sana".

\section{Data 7}

"tempat untuk santai yang di buat khusus untuk para turis"

kesalahan penulisan pada kata depan pada data (7) terdapat kata di buat seharusnya pada kata tersebut harus disambung dibuat karena tidak menunjukan keterangan tempat, ditulis sesuai penggunaan ejaan yang benar "tempat untuk santai yang dibuat khusus untuk 
para turis".

\section{Data 8}

"saya langsung berangkat pulang kerumah"

Kesalahan penulisan kata depan pada kata kerumah juga harus dipisah karena menunjukan keterangan tempat jadi, kata tersebut harus dipisah dengan kata yang mengikutinya kerumah berikut penggunaan kata depan yang tepat "saya langsung berangkat pulang ke rumah"

\section{Data 9}

"saya beristirahat sejenak karena terlalu keasikan melihat apa yang ada disana"

Paparan data (9) di atas, tampak kesalahan penulisan kata depan. Kesalahan itu dapat dilihat pada kata yang dicetak miring disana. Penulisan kata depan tersebut, secara EYD menyalahi kaidah, seharusnya kata depan tersebut ditulis terpisah dari kata yang mengikutinya disana oleh karena itu, agar penulisan kata depan di atas, sesuai dengan EYD, penulisannya dapat dilihat pada contoh berikut "saya beristirahat sejenak karena terlalu keasikan melihat apa yang ada di sana".

\section{Data 10}

"selfi-selfi bersama-sama diatas air"

Kesalahan penulisan kata depan pada data di atas, pada kata diatas pada kata tersebut menunjukan kesalahan penulisan kata depan yang seharusnya ditulis terdipisah dari induk katanya, maka dapat ditulis. "selfi-selfi bersama- sama di atas air"

\section{Kesalahan Penulisan Singkatan Data 11} "ada ayunan yg berdiri di tengah laut"
Kesalahan penulisan kata depan pada data (11) terdapat kata yg seharusnya kata tersebut harus ditulis secara keseluruhan yang karena tidak memiliki arti dalam penulisan singkatan maupun dalam penggunaan ejaan yang disempurnakan. Berikut penggunaan singkatan yang tepat "ada ayunan yang berdiri di tengah laut".

\section{Data 12}

"pada hari Minggu sy pergi ke wisata"

Kesalahan penulisan singkatan terdapat pada data (12) pada kata sy penggunaan singkatan pada kata tersebut tidak benar, kata tersebut harus ditulis secara keseluruhan saya. Berikut penulisan singkatan yang tepat "pada hari Minggu saya pergi ke wisata"

\section{Data 13}

"setelah saya merasakan suasana di pantai tanjung karang akhirnya sya pulang ke rumah"

Kesalahan penulisan singkatan terdapat pada data (13) pada kata sya penggunaan singkatan pada kata tersebut tidak benar, kata tersebut harus ditulis secara keseluruhan saya. Berikut penggunaan singkatan yang tepat "setelah saya merasakan suasana di pantai tanjung karang akhirnya saya pulang ke rumah"

\section{Kesalahan Penulisan Imbuhan Data 14}

"saya memfoto-foto dengan turis dan akhirnya saya pulang"

Kesalahan penulisan imbuhan tampak pada kata menfoto-foto yang seharusnya tidak menggunakan menggunakan awalan men 
karena ketika menggunakan kata men akan mengalami kerancuan dalam sebuah kata. Seharusnya pada kata tersebut menggunakan kata berfoto-foto yang berarti melakukan suatu kegiatan mengambil gambar. Jadi dapat ditulis "saya berfoto-foto dengan turis dan akhirnya saya pulang"

\section{Data 15}

"Ditilang polisi karena berlaju-laju lepas itu"

Pada kata kesalahan penulisan kata imbuhan tampak pada kata berlaju-laju, seharusnya pada kata tersebut tidak menggunakan kata ber karena kata tersebut akan mengalami kerancuan pada saat membaca. Saharusnya ditulis laju- laju yang artinya buru-buru. Jadi ditulis "Ditilang polisi karena laju-laju lepas itu"

\section{Data 16}

"aku menberenang-renang"

Pada kata tersebut terdapat kesalahan penulisan imbuhan pada kata menberenangrenang. Pada kata tersebut seharusnya tidak menggunakan imbuhan men karena pada kata tersebut akan mengalami kerancuan pada saat membaca kata tersebut. Jadi dapat ditulis tanpa mengguanakan imbuhan men "aku berenangrenang"

\section{Pembahasan}

Kesalahan penulisan kata pada karangan deskripsi siswa kelas VIII.1 SMP Negeri 2 Sekayu masih banyak mengalami kesalahan dalam penulisan karangan deskripsi, ini disebabkan karena kurangnya pemahaman siswa dalam penulisan kata, karena kurangnya pemahaman tersebut dapat mengakibatkan terjadinya kesalahan penulisan kata ulang, kata depan, singkatan kata, dan kata imbuhan.

Berdasarkan hasil penelitian pada 4.1 dalam analisis kesalahan penulisan kata pada karangan deskripsi pada siswa kelas VIII.1 SMP Negeri 2 Sekayu masih banyak mengalami kesalahan dalam menulis sebuah karangan deskripsi.

\section{KESIMPULAN}

Berdasarkan hasil penelitian dan pembahasan dapat ditarik kesimpulan sebagai berikut.

1. Kesalahan penulisan kata dalam karangan deskripsi siswa kelas VIII SMP Negeri 2 Sekayu, meliputi kesalahan kesalahan penulisan kata ulang, kata depan, singkatan kata, dan kata imbuhan.

2. Berdasarkan analisis kesalahan penulisan kata pada karangan deskripsi pada siswa kelas VIII.1 SMP Negeri 2 Sekayu masih banyak mengalami kesalahan dalam menulis sebuah karangan deskripsi.

\section{DAFTAR PUSTAKA}

Asrianti, Muhahad Taufik Matuges Dkk. (2014,2015).Panduan Tugas Akhir (Skripsi) dan Artikel Penelitian.Universitas Tadulako. Bingkai Ilmu Lewat Tulisan Kamis, 27 September 2012

Gantametrika dkk.(2016). Kesalahan Berbahasa Penggunaan EYD.Solo:Genta Smart Publisher.

Holisoh.(1996). Proses Pembelajaran di Sekolah. Bandung: Sinar Baru.

Kridalaksana Harimurti.(2001). Edisi Ketiga Kamus Linguistik. Jakarta: PT Gramedia Pustaka Utama. 
Kurnila, Nely. (2010). Tesis: Peningkatan Keterampilan Menulis Karangan Deskripsi dengan Menggunakan Metode Sugesti- Imajinatif melalui Media audio visual pada Siswa SMA Negeri 3 Ketapang Kalimantan Barat. Bandung: UPI.

Mulyati Yeti Dkk.(2010). Keterampilan Berbahasa Indonesia SD. Jakarta: Universitas Terbuka.

Satyawati Nanik. (2010). Analisis Kesalahan Bahasa Indonesia: Teori dan Praktik. Surakarta: Yuma Pustaka.

Semi, M. Atar. 1993. Metode Penelitian Sastra. Bandung: Angkasa.

Sulistiowati.(2008). Skripsi: Model Pembelajaran Menulis Karangan dengan Metode Karya Wisata. Bandung: Universitas Bale Bandung.

Suparno Dkk. (2007).Keterampilan Dasar Menulis.Jakarta: Universitas Terbuka.

Supriyadi.(1993). Pendidikan Bahasa Indonesia. Jakarta: Universitas Terbuka. Depdikbud.

Waridah Ernawati.(2008).EYD dan Seputar Kebahasaan Indonesia. Bandung. 